DOI 10.31558/2307-2318.2021.1.2

УДК 658.222.005

JEL: G31, G32,_C3

Болгов В.С.

к.е.н., доцент кафедри підприємництва, корпоративної та просторової економіки, Донецький національний університет імені Василя Стуса, м. Вінниця

ORCID: 0000-0002-0631-302X

v.bolgov@donnu.edu.ua

Витяганець I.М.

здобувач, Донецький національний університет імені Василя Стуса, м. Вінниця vytiahanets.i@donnu.edu.ua

\title{
ЗАБЕЗПЕЧЕННЯ ФІНАНСОВОЇ СТІЙКОСТІ ТА ПЛАТОСПРОМОЖНОСТІ ЯК ВАЖЛИВА ЦІЛЬ ВНУТРІШНЬОФІРМОВОГО БЮДЖЕТУВАННЯ
}

У статті обтрунтовано теоретичні засади та практичні рекомендацій щзодо оцінки платоспроможності та фінансової стійкості підприємства, визначено пріоритети $i$ розроблено системи засобів підвищення фінансової незалежності ПрАТ «Карлсберг Україна». Розглянуто сутнісні характеристики бюджетування як інструменту внутрішньофірмового фінансового планування. Досліджено механізм забезпечення таких понять як фінансова стійкість, ліквідність, платоспроможності підприємства, проаналізувати фактори, щцо здійснюють суттєвий вплив на їх формування та підтримку. Обгрунтовано методичний підхід оцінки фінансової стійкості ПрАТ «Карлсберг Україна». Проведено аналіз ліквідності та платоспроможності підприємства. Здійснено моделювання фінансової стійкості ПрАТ «Карлсберг Украӥна» з перспективою підвищення ефрективності його господарської діяльності. Виявлено та запропоновано иляхи підвищення ефективності використання фінансових ресурсів за допомогою факторного аналізу рентабельності власного капіталу ПрАТ «Карлсберг Україна».

Ключові слова: бюджетування, мотивачія, механізм, фінансова стійкість, платоспроможність, аналіз.

Табл. - 10, літ. -12

Постановка проблеми. Становлення механізму та застосування до багатьох підприємств інструментів усунення банкрутства дозволяє провести об'єктивний аналіз їх фінансового стану та має пріоритетне значення як для підприємств, так i для їх контрагентів, кредиторів, інвесторів, державних установ. Найбільш важливими характеристиками оцінки фінансової спроможності суб'єкта господарювання є показники платоспроможності та фінансової стійкості.

Відзначається, що бюджетування вважається єдиною технологією, яка охоплює основні аспекти діяльності підприємства, а також координує їх, що дозволяє досягати таких цілей, як максимізація прибутку, оптимізація витрат, балансова рівність здійснюваних витрат у порівнянні з фінансовими ресурсами, що залучаються, координація грошових потоків, тобто підвищення фінансового становища підприємства.

Бюджетування сьогодні - це один із основних інструментів керівництва, який дозволяє підвищити ефективність організації, оскільки застосування бюджетування дає 
можливість управлінцям здійснювати контроль над станом справ підконтрольних підрозділів підприємства, створювати умови їх взаємодії для досягнення спільної мети їх діяльності. Також необхідно відзначити, що головною метою бюджетування є підвищення фінансово-економічної ефективності підприємства, а також його фінансової стійкості через координацію роботи всіх підрозділів цього підприємства на досягнення кінцевого результату.

Аналіз останніх досліджень та публікацій. Дослідженням формування та проблематики управління фінансовою стійкістю підприємств присвячено чимало праць як вітчизняних так і зарубіжних науковців, серед яких можна відзначити Е. Альтмана, А. Томпсона, В. Бочарова, В. Іванова, В. Ковальова, Л. Лахтіонову, В. Павловську, А. Поддєрьогіна, Р. Сайфуліна, Р. Савицьку, А. Шеремета, Е. Хелферта, Р. Фатхутдинова та багато інших.

Метою статті $\epsilon$ обгрунтування теоретичних засад та практичних рекомендацій щодо оцінки платоспроможності та фінансової стійкості підприємства, визначення пріоритетів і розроблення системи засобів підвищення фінансової незалежності ПрАТ «Карлсберг Україна».

Виклад основного матеріалу. Сучасна економічна ситуація в нашій країні, структурні, правові та майнові зміни у вітчизняній промисловості, посилення конкуренції неминуче викликають необхідність доповнення стратегічно орієнтованих програм розвитку підприємств системою внутрішньофірмового бюджетування.

Враховуючи різносторонність наукових підходів, під бюджетуванням часто розуміють так зване казначейське бюджетування, тобто регламент керування коштами, використовуваними в операційній діяльності комерційної організації. У світовій практиці бюджетування - це елемент менеджменту, орієнтований на керування комерційною організацією (у грошових показниках), що представляє собою методологію планування, обліку й контролю коштів і фінансових результатів [1].

Для досягнення довготривалого успіху робота по впровадженню внутрішньофірмового бюджетування має здійснюватися за основними його принципами:

по-перше, застосування методології бюджетування, що базується на західних принципах фінансового менеджменту, адаптованої до вітчизняних умов;

по-друге, створення корпоративних баз даних, які грунтуються на зборі первинної документації та подальшої іiі обробки, в тому числі інформації бухгалтерської звітності, в більш оперативному режимі, ніж терміни звітності;

по-третє, чітке слідування принципам конфіденційності.

Бюджетування - складна система що включає:

сукупність взаємозалежної розробленої документації, у якій 3 обгрунтованим ступенем деталізації показників відображена запланована діяльність, як окремих центрів фінансової відповідальності (ЦФВ), так і підприємства загалом;

управлінський контроль на ЦФВ, орієнтований на мінімізацію відхилень від бюджету з урахуванням постійної трансформації зовнішнього середовища;

звітність ЦФВ, що дозволяє оперативно аналізувати та контролювати виконання бюджетів окремими підрозділами ЦФВ для досягнення запланованих підприємством фінансових результатів [2].

Бюджетування підприємства дає можливість отримати конкурентну перевагу через створення дієвої системи управління ресурсами, прогнозуючи можливі труднощі та належним чином аналізувати майбутні дії. Таким чином, актуальною дилемою для сучасних компаній є впровадження і прогресивний розвиток системи бюджетування, яка, в 
ролі управлінської технології дозволяє менеджменту отримувати в своє розпорядження загальну картину функціонування підприємства, а також його фінансового становища.

Однією 3 неодмінних умов досягнення високої ефективності функціонування ринкового механізму є ліквідація збанкрутілих підприємницьких організацій з ринкового простору. Фінансова стійкість - один із найважливіших параметрів фінансового стану підприємства, від його рівня залежить збалансованість розвитку та рівень конкурентоспроможності суб'єкта господарювання. Забезпечення й підтримка оптимального рівня фінансової стійкості $\epsilon$ одним 3 найбільш важливих завдань господарської діяльності кожного підприємства, оскільки низькі показники фінансової стійкості можуть призвести підприємство до стану неплатоспроможності, а також подальшого банкрутства. Але в той же час високі показники фінансової стійкості свідчать про неефективну господарську діяльність підприємства.

Фінансова стійкість формується в процесі всієї господарської діяльності і є головним компонентом загальної стійкості підприємства, на стан якої впливають різні фактори: положення підприємства на товарному ринку; ступінь охоплення ринку збуту; виробництво та випуск дешевої, якісної продукції, що користується попитом на ринку; потенціал підприємства в діловому співробітництві; рівень залежності від зовнішніх кредиторів та інвесторів; наявність неплатоспроможних дебіторів; ефективність господарських і фінансових операцій, тощо.

Що стосується таких категорій «ліквідність» та «платоспроможність» підприємства, у вітчизняній економічній теорії та практиці відсутня однозначність у розумінні сутності даних понять, а отже, й системи їх оцінювання. Слід звернути увагу, що поняття ліквідності та платоспроможності тісно взаємопов'язані, але не тотожні. Відзначимо, що поняття «ліквідність» співвідноситься як 3 конкретними видами активів, так і 3 їх сукупністю в цілому та з підприємством як суб'єктом фінансових відносин.

Найбільш загальне визначення платоспроможності дають Л. В. Донцова та І. А. Нікифорова: «Платоспроможність це здатність підприємства своєчасно та повністю відповідати за своїми зобов'язаннями, виступає у формі зовнішнього прояву фінансової стійкості, сутністю якої є забезпеченість оборотних активів довгостроковими джерелами формування, яка гарантуватиме його постійну платоспроможність» [3].

Ліквідність балансу визначається як ступінь покриття боргових платіжних зобов'язань організації іiі активами, термін обернення яких у грошову форму відповідає терміну погашення платіжних зобов'язань. Ліквідність активів - це час перетворення активів у готівку, чим менше буде потрібно часу, щоб даний вид активів набув грошову форму, тим вища його ліквідність. Ліквідність підприємства - це здатність суб' єкта господарювання нести відповідальність внутрішніми оборотними активами в кількості, достатній для розрахунків роздільно, або в цілому, за своїми платіжними зобов'язаннями, що вимагають негайного погашення у будь-який момент часу поточного і планового періодів згідно з підписаними договорами, при цьому вона може супроводжуватися як приростом активів, так і накопиченням пасивів [12].

Платоспроможність підприємства, безпосередньо залежить від рівня ліквідності та відповідно від факторів, які визначають дану категорію. Існує перелік специфічних чинників, властивих формуванню власне поняттю платоспроможності підприємства:

тривалість фінансового та операційного циклів;

відповідність фінансової діяльності підприємства та його контрагентів платіжній дисципліні;

належна обгрунтованість стратегічного та фінансового планування, вичерпність й ефективність його виконання; 
швидкість обороту маси грошового капіталу.

Стабільний стан підприємства означає його платоспроможність та достатню ліквідність. Процес управління платоспроможністю підприємства представлений у вигляді алгоритму циклічної діяльності, пов'язаної з виявленням факторів, які впливають на ліквідність та платоспроможність, з пошуком і організацією виконання фінансових рішень. Аналіз платоспроможності підприємства включає в себе такі основні пункти:

структурний аналіз активних і пасивних статей балансу, тобто аналіз ліквідності балансу підприємства;

розрахунок коефіцієнтів фінансової ліквідності;

розрахунок коефіцієнта платоспроможності.

Приватне акціонерне товариство «Карлсберг Україна»є частиною Carlsberg Group, однієї з найвідоміших пивоварних груп у світі, найбільшого данського інвестора на території України, з великим портфелем брендів пива та інших напоїв, яка стабільно працює і здійснює позитивний внесок в розвиток суспільства на всіх ринках свого господарювання [7]. Дослідивши основні методи та критерії визначення фінансової стійкості та платоспроможності підприємства, було визначено, що найбільш придатною $є$ модель оцінки фінансової стійкості ПрАТ «Карлсберг Україна» за критерієм стабільності джерел покриття запасів, відповідно до якої проф. В. В. Ковальов виділяє такі типи фінансової стійкості суб'єкта господарювання [8]:

1. Абсолютна фінансова стійкість - E1, E2, E3 > 0 (трикомпонентний показник даного типу фінансової стійкості має вигляд $Ф \mathrm{C}=\{1,1,1\})$;

2. Нормальна фінансова стійкість $-\mathrm{E} 1<0, \mathrm{E} 2>0, \mathrm{E} 3>0(\Phi \mathrm{C}=\{0,1,1\})$;

3. Нестійкий (передкризовий) фінансовий стан $-\mathrm{E} 1<0, \mathrm{E} 2<0, \mathrm{E} 3>0(\Phi \mathrm{C}=\{0,0,1\})$;

4. Кризовий фінансовий стан $-\mathrm{E} 1<0, \mathrm{E} 2<0, \mathrm{E} 3<0(\Phi \mathrm{C}=\{0,0,0\})$.

Разом 3 абсолютними показниками доцільно застосувати коефіцієнтний метод фінансового аналізу [4], який передбачає розрахунок сукупності часткових аналітичних показників - коефіцієнтів ліквідності, платоспроможності, ринкової стійкості, використання яких надає користувачам більш об'єктивну інформацію.

На основі річної фінансової звітності Товариства $[5,6,7]$ здійснимо розрахунок узагальнюючих показників фінансової стійкості ПрАТ «Карлсберг Україна» за період 20172019 pр. (табл. 1). Проаналізувавши результати розрахунків загальних показників фінансової стійкості ПрАТ «Карлсберг Україна», можна зробити висновок, що підприємство має абсолютну фінансову стійкість. Отже, у Товариства досить власних коштів для покриття запасів і витрат, що свідчить про його ефективну фінансову діяльність. ПрАТ «Карлсберг Україна» має високу платоспроможність та незалежність від зовнішнього фінансування.

Запас стійкості фінансового стану у 2017 р. вимірювався в обсязі 35,11 днів, відповідно у 2019 р. даний показник значно зменшився і склав 9,92 днів. Дані таблиці 1 свідчать, що за період 2017-2019 рр. Товариство мало можливість для покриття усіма основними джерелами запасів, що підтверджує абсолютну стійкість. Причому, якщо в 2017 p. надлишок коштів на 1 грн запасів склав 1,53 грн, то на кінець 2019 р. - 0,35 грн, що відбулося внаслідок зростання величини запасів у 2 рази (на 271299 тис. грн). Це збільшення запасів перекрило зростання статей їх покриття - виникнення довгострокових зобов'язань на 41111 тис. грн і збільшення короткострокових кредитів і позик на 22391 тис. грн. 
Таблиця 1 - Абсолютні показники фінансової стійкості ПрАТ «Карлсберг Україна» за період 2017-2019 рр, тис. грн

\begin{tabular}{|c|c|c|c|c|c|c|}
\hline \multirow[b]{2}{*}{ № } & \multirow[b]{2}{*}{ Показник } & \multirow[b]{2}{*}{2017} & \multirow[b]{2}{*}{2018} & \multirow[b]{2}{*}{2019} & \multicolumn{2}{|c|}{ Зміна $(+,-)$} \\
\hline & & & & & $\begin{array}{c}2018 / \\
2017 \\
\end{array}$ & $\begin{array}{c}2019 / \\
2018 \\
\end{array}$ \\
\hline 1 & Оборотні активи, тис. грн & 2498964 & 2354908 & 2460814 & -144056 & 105906 \\
\hline 2 & $\begin{array}{l}\text { Матеріальні оборотні запаси, (H4) тис. } \\
\text { грн }\end{array}$ & 324712 & 500226 & 596011 & 175514 & 95785 \\
\hline 3 & Товарні запаси, тис. грн & 1593 & 7156 & 8220 & 5563 & 1064 \\
\hline 4 & Власний капітал, тис. грн & 3079836 & 2872187 & 2942420 & -207649 & 70233 \\
\hline 5 & $\begin{array}{l}\text { Власний оборотний капітал (ВОК) або } \\
\text { наявність власних джерел фінансування } \\
\text { запасів (H1), тис. грн }\end{array}$ & 822195 & 768588 & 720543 & -53607 & -48045 \\
\hline 6 & Довгострокові зобов'язання, тис. грн & - & - & 41111 & - & 41111 \\
\hline 7 & $\begin{array}{l}\text { Функціонуючий капітал (ФК) або } \\
\text { наявність власних та довгострокових } \\
\text { джерел фінансування запасів (Н2), тис. } \\
\text { грн }\end{array}$ & 822195 & 768588 & 761654 & -53607 & -6934 \\
\hline 8 & Короткострокові кредити банків, тис. грн & 1676769 & 1586320 & 1699160 & -90449 & 112840 \\
\hline 9 & $\begin{array}{l}\text { Загальна величина основних джерел } \\
\text { фінансування запасів (ЗД) або (Н3), тис. } \\
\text { грн }\end{array}$ & 822195 & 768588 & 802765 & -53607 & 34177 \\
\hline 10 & $\begin{array}{l}\text { Надлишок (+) чи недостатність (-) ВОК } \\
(Ф С(\text { вок)) або (Е1), тис. грн }\end{array}$ & 497483 & 268362 & 124532 & -229121 & -143830 \\
\hline 11 & $\begin{array}{l}\text { Надлишок (+) чи недостатність (-) ФК } \\
(\Phi С(ф к)) \text { або (Е2), тис. грн }\end{array}$ & 497483 & 268362 & 165643 & -229121 & -102719 \\
\hline 12 & $\begin{array}{l}\text { Надлишок (+) чи недостатність (-) ЗД } \\
(\text { ФС(зд)) або (Е3), тис. грн }\end{array}$ & 497483 & 268362 & 206754 & -229121 & -61608 \\
\hline 13 & $\begin{array}{l}\text { Значення трьохкомпонентного показника } \\
\text { фінансової сталості (ФС) }\end{array}$ & $\{1 ; 1 ; 1\}$ & $\{1 ; 1 ; 1\}$ & $\{1 ; 1 ; 1\}$ & - & - \\
\hline 14 & Тип фінансової сталості & абсолютна & абсолютна & абсолютна & - & - \\
\hline 15 & Запас стійкості фінансового стану, днів & 35,11 & 16,19 & 9,92 & $-18,92$ & $-6,27$ \\
\hline 16 & $\begin{array}{l}\text { Надлишок (+), нестача (-) загальних } \\
\text { джерел на } 1 \text { грн. запасів, грн }\end{array}$ & 1,53 & 0,54 & 0,35 & $-0,99$ & $-0,19$ \\
\hline
\end{tabular}

$$
\text { Джерело: розраховано автором }
$$

Наступним етапом оцінювання фінансової стійкості ПрАТ «Карлсберг Україна» $є$ дослідження відносних показників (табл. 2), застосування яких дозволяє більш детально іiі оцінити, виокремити фактори за рахунок яких відбуваються зміни у стійкості суб'єкта господарювання, характеризує структуру джерел фінансування ресурсів підприємства, стабільність фінансової безпеки та незалежності від зовнішніх джерел фінансування його діяльності.

Аналітичні дані табл. 2 дозволяють стверджувати про наявність передумов забезпечення фінансової стійкості Товариства. За період 2017-2018 pp. - 65\%, протягом 2019 р. - 62\% майна було профінансовано за власний рахунок Товариства. Перевищення значення коефіцієнта автономії нормативного рівня свідчить про стабільну структуру капіталу та меншу залежність ПрАТ «Карлсберг Україна» від зовнішніх джерел фінансування. Виходячи 3 аналізу 2017-2018 рр. коефіцієнт довгострокового залучення капіталу дорівнює 0, оскільки Товариство не використовувало довгострокові зобов'язання. У 2019 р. показник становив 0,014 - частка фінансування діяльності за рахунок залучення довгострокових кредитів та позик залишається досить не значною. Показник фінансової залежності досліджуваного періоду перевищує 1 та збільшується в динаміці на 0,05 пунктів 
протягом 2017-2019 рр, що свідчить про підвищення рівня фінансової залежності Товариства.

Наступний коефіцієнт фінансової стійкості знаходиться в межах нормативного значення, пояснюється можливістю Товариства залишатися платоспроможним і проводити свою діяльність в довгій перспективі, означає, що 63-65\% активів ПрАТ «Карлсберг Україна» фінансує за рахунок власного капіталу та довгострокових зобов'язань. Період 2017-2019 рр. характеризується сталим веденням виробничої діяльності за рахунок значної частки власних ресурсів, про що свідчить значення показника фінансової стабільності, який в 2019 р. становив 1,69. Товариство стабільно генерує грошові потоки, внаслідок цього, не виникає ускладнень при відшкодуванні заборгованості.

Таблиця 2 - Аналіз відносних показників фінансової стійкості ПрАТ «Карлсберг Україна» за 2017-2019 pp.

\begin{tabular}{|c|c|c|c|c|c|c|}
\hline \multirow{2}{*}{ Назва показника } & \multirow{2}{*}{$\begin{array}{l}\text { Нормативне } \\
\text { значення }\end{array}$} & \multirow{2}{*}{2017} & \multirow{2}{*}{2018} & \multirow{2}{*}{2019} & \multicolumn{2}{|c|}{$\begin{array}{c}\text { Абсолютне } \\
\text { відхилення, тис. грн }\end{array}$} \\
\hline & & & & & $\begin{array}{l}2018 / \\
2017\end{array}$ & $\begin{array}{l}2019 / \\
2018\end{array}$ \\
\hline 1. Коефіцієнт автономії & $\geq 0,5$ & 0,65 & 0,65 & 0,62 & $-0,01$ & $-0,02$ \\
\hline $\begin{array}{l}\text { 2. Коефіцієнт довгострокового залучення } \\
\text { капіталу }\end{array}$ & $<1$ & - & - & 0,014 & - & 0,014 \\
\hline 3. Коефіцієнт фінансової залежності & $\leq 1$ & 1,54 & 1,55 & 1,59 & 0,01 & 0,04 \\
\hline 4. Коефіцієнт фінансової стійкості & $0,5-1,0$ & 0,65 & 0,64 & 0,63 & $-0,01$ & $-0,01$ \\
\hline 5. Коефіцієнт фінансової стабільності & $\geq 0,67$ & 1,84 & 1,81 & 1,69 & $-0,03$ & $-0,12$ \\
\hline $\begin{array}{l}\text { 6. Коефіцієнт забезпечення оборотних активів } \\
\text { власними оборотними коштами }\end{array}$ & $\geq 0,1$ & 0,33 & 0,33 & 0,29 & 0 & $-0,04$ \\
\hline 7. Коефіцієнт маневреності власного капіталу & $\geq 0,4$ & 0,27 & 0,27 & 0,25 & 0 & $-0,02$ \\
\hline $\begin{array}{l}\text { 8. Коефіцієнт структури покриття } \\
\text { довгострокових вкладень }\end{array}$ & зменшення & - & - & 0,019 & - & 0,019 \\
\hline $\begin{array}{l}\text { 9. Коефіцієнт концентрації позикового } \\
\text { капіталу }\end{array}$ & $\leq 0,5$ & 0,35 & 0,36 & 0,37 & 0,01 & 0,01 \\
\hline 10. Коефіцієнт інвестування & $0,4-1$ & 0,65 & 0,64 & 0,63 & $-0,01$ & $-0,01$ \\
\hline $\begin{array}{l}\text { 11. Коефіціснт реальної вартості основних } \\
\text { засобів }\end{array}$ & $\geq 0,5$ & 0,40 & 0,41 & 0,42 & 0,01 & 0,01 \\
\hline 12. Коефіціснт нагромадження амортизації & $<0,5$ & 0,58 & 0,62 & 0,63 & 0,04 & 0,01 \\
\hline $\begin{array}{l}\text { 13. Коефіцієнт стійкості економічного } \\
\text { зростання }\end{array}$ & $\geq 0,5$ & 0,65 & 0,63 & 0,63 & $-0,02$ & 0 \\
\hline
\end{tabular}

Джерело: розраховано автором

Коефіцієнт забезпеченості власними оборотними засобами перевищує мінімальне значення та складає 0,33 - Товариство здатне самостійно фінансувати оборотний капітал. Зменшення показника в 2019 р. на 0,04 пункти пояснюється залученням довгострокових джерел фінансування. Коефіцієнт маневреності власного капіталу у 2019 р. складає 0,25, характеризує низький рівень фінансового забезпечення господарської діяльності ПрАТ «Карлсберг Україна» власним капіталом. Розрахунок коефіцієнта структури покриття довгострокових вкладень був здійснений тільки в 2019 р., оскільки у 2017-2018 рр. Товариство не мало довгострокових зобов'язань, його значення 0,019, означає, що підприємство не в значній мірі залежить від зовнішнього фінансування. Більш детально описує ситуацію із залученими коштами коефіцієнт концентрації позикового капіталу, який за період 2017-2019 рр. знаходиться нижче оптимального рівня, отже в 2019 р. тільки 37\% активів фінансується за рахунок зобов'язань.

Здійснивши аналіз зміни коефіцієнта інвестування можемо відмітити, що за 20172019 рр. ПрАТ «Карлсберг Україна» має достатньо власного капіталу для покриття 
поточної потреби в необоротних активах і участі у формуванні оборотних активів. Частка реальної вартості основних засобів у валюті балансу має тенденцію до зростання, отже виробничий потенціал Товариства теж збільшується. Зростання коефіцієнта нагромадження амортизації та його значення на рівні 63\% характеризує збільшення концентрації вивільнення нематеріальних активів та основних засобів, дає більше можливостей покращення фінансового стану. Коефіцієнт стійкості економічного зростання ПрАТ «Карлсберг Україна» за аналізований період 2017-2019 рр. вказує, що в 2017 р. для формування 1 грн власних активів Товариство реінвестує 0,65 грн чистого прибутку, у 2018 та 2019 pp. - 0,63 грн відповідно. Отже, результати аналізу дозволяють стверджувати про наявність стійкого фінансового стану ПрАТ «Карлсберг Україна», на що вказують значення і тенденція зміни абсолютних та відносних фінансових показників. Попри факт зменшення більшості коефіцієнтів протягом аналізованого періоду, необхідно відмітити, що всі вони знаходяться в межах нормативного значення.

Дослідження платоспроможності підприємства починається 3 аналізу ліквідності його балансу, шо полягає в структурному порівнянні коштів по активу, з позиції їх мобільності, згрупованих за ступенем спадної ліквідності, 3 короткостроковими зобов'язаннями по пасиву, які вирівнюються по терміновості їх оплати. Розпочнемо оцінку ліквідності балансу ПрАТ «Карлсберг Україна» зі співставлення даних активу та пасиву за ступенем їх ліквідності за період 2017-2019 рр. (табл. 3).

Таблиця 3 - Аналіз ліквідності балансу ПрАТ «Карлсберг Україна» за період 20172019 рр., тис. грн.

\begin{tabular}{|c|c|c|c|c|c|c|c|}
\hline \multirow{2}{*}{$\begin{array}{c}\text { Група активів, тис. } \\
\text { грн }\end{array}$} & \multicolumn{3}{|c|}{ Період } & \multirow{2}{*}{$\underset{\text { Грнн }}{\Gamma \text { рупа пасивів, тис. }}$} & \multicolumn{3}{|c|}{ Період } \\
\hline & 2017 & 2018 & 2019 & & 2017 & 2018 & 2019 \\
\hline A1 & 1631139 & 1262637 & 1159142 & $\Pi 1$ & 241349 & 280220 & 386909 \\
\hline $\mathrm{A} 2$ & 696023 & 872716 & 915145 & $\Pi 2$ & 851319 & 1179196 & 1197730 \\
\hline A3 & 161009 & 224124 & 357546 & $\Pi 3$ & 584101 & 132846 & 114521 \\
\hline A4 & 2235697 & 2104359 & 2199943 & $\Pi 4$ & 3079836 & 2916873 & 2983531 \\
\hline \multicolumn{2}{|c|}{ Умова стійкої ліквідності } & \multicolumn{2}{|c|}{$\begin{array}{c}\text { Результат на кінець } \\
2017 \text { p. }\end{array}$} & \multicolumn{2}{|c|}{ Результат на кінець 2018 р. } & \multicolumn{2}{|c|}{$\begin{array}{c}\text { Результат на кінець } \\
2019 \text { р. }\end{array}$} \\
\hline \multicolumn{2}{|l|}{$\geq$} & \multicolumn{2}{|c|}{$\geq$} & \multicolumn{2}{|l|}{$\geq$} & \multicolumn{2}{|c|}{$\geq$} \\
\hline \multicolumn{2}{|l|}{$\geq$} & \multicolumn{2}{|c|}{$\leq$} & \multicolumn{2}{|l|}{$\leq$} & \multicolumn{2}{|c|}{$\leq$} \\
\hline \multicolumn{2}{|l|}{$\geq$} & \multicolumn{2}{|c|}{$\leq$} & \multicolumn{2}{|l|}{$\geq$} & \multicolumn{2}{|c|}{$\geq$} \\
\hline \multicolumn{2}{|l|}{$\leq$} & \multicolumn{2}{|c|}{$\leq$} & \multicolumn{2}{|l|}{$\leq$} & \multicolumn{2}{|c|}{$\leq$} \\
\hline
\end{tabular}

Джерело: розраховано автором

Баланс буде вважатися ліквідним за умови дотримання між групами активів i зобов'язань наступних співвідношень:

$$
\mathrm{A} 1 \geq \Pi 1, \mathrm{~A} 2 \geq \Pi 2, \mathrm{~A} 3 \geq \Pi 3, \mathrm{~A} 4<\Pi 4 .
$$

3 огляду на вищезазначені співставлення результатів, можна зробити висновок, що баланс ПрАТ «Карлсберг Україна» у 2017 р. не є абсолютно ліквідним, тому що зберігаються тільки дві нерівності. Зіставлення А1-П1 і А2-П2 дозволяє виявити поточну ліквідність підприємства, що свідчить про неплатоспроможність Товариства найближчим часом. Результат 2018-2019 рр. також повністю відхиляється від нормативного значення абсолютної ліквідності, залишаються оптимальними три співвідношення, що свідчить про часткову ліквідність Товариства. Порівняння А3-ПЗ відображає перспективну ліквідність, на основі якої прогнозується довгострокова орієнтовна платоспроможність. Однак збереження останнього співвідношення, який носить балансуючий характер 3 глибоким економічним змістом, свідчить про наявність у підприємства власного оборотного капіталу. 
Тобто ПрАТ «Карлсберг Україна» протягом 2017-2019 рр. дотримується мінімальної ліквідності, що є вагомим аргументом у зазначені фінансового стану Товариства на досить стабільному рівні.

Більш детально розглянути та проаналізувати ліквідність можна за допомогою низки основних коефіцієнтів ліквідності, розрахунок яких здійснимо на основі даних Форми № 1 «Баланс» і Форми 2 «Звіт про фінансові результати» (табл. 4).

Таблиця 4 - Результати відносних показників ліквідності ПрАТ «Карлсберг Україна» за 2017-2019 рр.

\begin{tabular}{|c|c|c|c|c|c|c|}
\hline \multirow{2}{*}{ Назва показника } & \multirow{2}{*}{$\begin{array}{l}\text { Нормативне } \\
\text { значення }\end{array}$} & \multirow{2}{*}{2017} & \multirow{2}{*}{2018} & \multirow{2}{*}{2019} & \multicolumn{2}{|c|}{$\begin{array}{c}\text { Абсолютне } \\
\text { відхилення, тис. грн }\end{array}$} \\
\hline & & & & & $\begin{array}{l}2018 \text { від } \\
2017\end{array}$ & $\begin{array}{c}2019 \text { від } \\
2018\end{array}$ \\
\hline $\begin{array}{l}\text { 1. Величина власних оборотних коштів } \\
\text { (робочий, функціонуючий капітал) }\end{array}$ & $>0$ & 1,49 & 1,48 & 1,45 & $-0,01$ & $-0,03$ \\
\hline 2. Коефіцієнт співвідношення активів & $>1$ & 1,11 & 1,12 & 1,11 & 0,01 & $-0,01$ \\
\hline 3. Коефіцієнт мобільності активів & $\geq 0,5$, & 0,53 & 0,53 & 0,53 & 0 & 0 \\
\hline $\begin{array}{l}\text { 4. Коефіцієнт ліквідності коштів у } \\
\text { розрахунках }\end{array}$ & - & 0,32 & 0,41 & 0,40 & 0,09 & $-0,01$ \\
\hline 5. Коефіцієнт загальної ліквідності & $1-2$ & 1,49 & 1,48 & 1,44 & $-0,01$ & $-0,04$ \\
\hline 6. Коефіцієнт абсолютної ліквідності & $\geq 0,2$ & 0,97 & 0,76 & 0,68 & $-0,21$ & $-0,08$ \\
\hline 7. Коефіцієнт термінової ліквідності & $0,8-1,0$ & 1,30 & 1,17 & 1,10 & $-0,13$ & $-0,07$ \\
\hline $\begin{array}{l}\text { 8. Співвідношення короткострокової } \\
\text { дебіторської та кредиторської } \\
\text { заборгованості }\end{array}$ & $\mathrm{K}=1$ & 3,11 & 2,45 & 2,43 & $-0,66$ & $-0,02$ \\
\hline 9. Частка оборотних коштів у активах, \% & $>0,5$ & 53 & 53 & 53 & 0 & 0 \\
\hline $\begin{array}{l}\text { 10. Частка власних оборотних коштів у } \\
\text { покритті запасів, \% }\end{array}$ & $=0,5$ & 253 & 154 & 121 & $-99,00$ & $-33,00$ \\
\hline
\end{tabular}

Джерело: розраховано автором

Результати розрахунків коефіцієнтів ліквідності дозволяють зробити наступні висновки 3 приводу платоспроможності ПрАТ «Карлсберг Україна». Щодо величини власних оборотних коштів, то в 2017-2019 pр. робочий капітал доступний та ефективно використовується, що позитивно впливає на щоденну операційну діяльність Товариства. Коефіцієнт співвідношення активів за період 2017-2019 рр. знаходиться на рівні 1,11-1,12, що позитивно відображається в господарській діяльності Товариства. Зростання показника в 2018 р. пояснюється придбанням додаткових основних засобів. Частка оборотних i прирівняних до них активів у майні Товариства - 53\%, свідчить про достатню ліквідність активів підприємства. Коефіцієнт ліквідності коштів у розрахунках на кінець 2019 р. становить 0,4 - це означає, що 40\% очікуваних надходжень дебіторської заборгованості будуть використані для погашення поточних зобов'язань Товариства.

Загальний коефіцієнт поточної ліквідності на кінець 2019 р. досяг значення 1,44 при оптимальному значенні 1-2 та скоротився за звітний період на 0,05 пункти. Зазначимо, що результати розрахунків свідчать про практичну здатність Товариства покрити зобов'язання за рахунок тільки оборотних активів. Значення коефіцієнта абсолютної ліквідності свідчить про те, що в 2019 р. 68\% короткострокової заборгованості Товариство здатне погасити терміново, а отже в ПрАТ «Карлсберг Україна» достатня кількість ліквідних оборотних коштів для погашення короткострокових зобов'язань у випадку його критичного стану. Оскільки, показники абсолютної і термінової ліквідності перевищують нормативні значення, спостерігається скорочення темпів росту поточної заборгованості над темпами росту високоліквідних активів підприємства. 
Питома вага оборотних засобів в майні Товариства становить 53\%, про що свідчить показник частки оборотних коштів в активах підприємства. Щодо частки власних оборотних коштів у покритті запасів, за період дослідження 2017-2019 рр., спостерігається тенденція повного відшкодування вартості запасів власними оборотними коштами.

3 метою аналізу фінансової стабільності ПрАТ «Карлсберг Україна» варто скористатися показниками платоспроможності, результати яких представлені в табл. 5.

Таблиця 5 - Результати часткових показників платоспроможності ПрАТ «Карлсберг Україна» за 2017-2019 рр.

\begin{tabular}{|l|c|c|c|c|c|c|}
\hline \multicolumn{1}{|c|}{ Назва показника } & $\begin{array}{c}\text { Норматив } \\
\text { не } \\
\text { значення }\end{array}$ & 2017 & 2018 & 2019 & \multicolumn{3}{|c|}{ Абсолютне } \\
\cline { 5 - 8 } & відхилення, тис. грн & $\begin{array}{c}2018 \text { від } \\
2017\end{array}$ & $\begin{array}{c}2019 \text { від } \\
2018\end{array}$ \\
\hline 1. Коефіцієнт ліквідної платоспроможності & $\geq 1$ & 1,49 & 1,49 & 1,42 & 0 & $-0,07$ \\
\hline $\begin{array}{l}\text { 2. Частка кредиторської заборгованості у } \\
\text { власному капіталі і дебіторській заборгованості }\end{array}$ & зниження & 0,46 & 0,45 & 0,47 & $-0,01$ & 0,02 \\
\hline $\begin{array}{l}\text { 3. Співвідношення нерозподіленого прибутку і } \\
\text { всієї суми активів }\end{array}$ & $\begin{array}{c}\text { збільшенн } \\
\text { я }\end{array}$ & 0,39 & 0,37 & 0,37 & $-0,02$ & 0 \\
\hline 4. Коефіцієнт фінансового левериджу & $<0,3$ & 0,54 & 0,55 & 0,59 & 0,01 & 0,04 \\
\hline 5. Коефіцієнт чистої виручки & $>0,3$ & 0,26 & 0,24 & 0,27 & $-0,02$ & 0,03 \\
\hline 6. Коефіцієнт Бівера & - & 0,78 & 0,92 & 1,18 & 0,14 & 0,26 \\
\hline
\end{tabular}

Джерело: розраховано автором

Таким чином, коефіцієнт ліквідної платоспроможності протягом 2017-2019 pp. перевищує норматив, визначає абсолютну платоспроможність, тобто ПрАТ «Карлсберг Україна» достатньо забезпечене оборотними засобами для повного покриття власних боргових зобов'язань. Слід зазначити, що частка кредиторської заборгованості у джерелах формування майна Товариства збільшується, внаслідок цього зростає фінансова залежність ПрАТ «Карлсберг Україна» від кредиторів. Тенденція зміни відносного показника співвідношення нерозподіленого прибутку до всієї суми активів відображує зниження прибутковості Товариства на 0,02 пункти за період дослідження 2017-2019 pp.

Динаміка коефіцієнта структури капіталу або фінансового левериджу за період 20172019 рр. відповідає негативній тенденції збільшення частки боргового капіталу в загальній структурі капіталу, а отже, більшому ризику структури капіталу. Здійснивши аналіз зміни коефіцієнта чистої виручки можемо відмітити, що протягом всього періоду дослідження його значення менше нормативного, однак має тенденцію до зростання. Результат розрахунку коефіцієнта Бівера для ПрАТ «Карлсберг Україна» свідчить про мінімальну загрозу неплатоспроможності протягом 2017-2019 pр. та його стійке фінансове становище.

3 проведеного аналізу можна зробити висновок, що основними чинниками підвищення ліквідності та платоспроможності підприємства є збільшення обсягів власного капіталу, скорочення величини понаднормативних запасів, отримання довгострокового фінансування, продаж частини постійних активів, вдосконалення роботи зі стягнення дебіторської заборгованості. Позитивно позначиться на підвищенні рівня ліквідності й залучення додаткових джерел фінансування на довгостроковій основі, збільшення власних коштів підприємства, які поповнюватимуться за рахунок спрямування чистого прибутку на розвиток організації, також зростання величини статутного капіталу шляхом залучення додаткових вкладів від власників.

Фінансова стійкість підприємства передбачає такий стан фінансових ресурсів, при раціональному розпорядженні якими гарантується наявність власних коштів, забезпечення процесу розширеного відтворення. Відсутність фінансової стійкості підприємства часто 
визначає неспроможність створення надлишкових запасів і резервів, що збільшує вартість залучення їх, стримує темпи розвитку підприємства. Таким чином, аналіз фінансової стійкості підприємства є важливим елементом фінансового менеджменту та аудиту.

У зв'язку з цим був проведений регресійний аналіз впливу на рівень фінансової стійкості підприємства, в якості результуючого показника обрано коефіцієнт автономії (Y), що характеризує фінансову незалежність Товариства від зовнішніх джерел фінансування, наступних детермінант: коефіцієнт забезпечення оборотних активів власними оборотними коштами $\left(\mathrm{X}_{1}\right)$; коефіцієнт маневреності власного капіталу $\left(\mathrm{X}_{2}\right)$; коефіцієнт стійкості економічного зростання $\left(\mathrm{X}_{3}\right)$; коефіцієнт фінансового левериджу $\left(\mathrm{X}_{4}\right)$; коефіцієнт рентабельності власного капіталу $\left(\mathrm{X}_{5}\right)$. Кореляційно-регресійний аналіз здійснено на основі фінансових показників за 24 квартали господарської діяльності ПрАТ «Карлсберг Україна».

Таблиця 6 - Матриця парних коефіцієнтів кореляції детермінант фінансової стійкості ПрАТ «Карлсберг Україна»

\begin{tabular}{|c|c|c|c|c|c|c|}
\hline Фактори & $\mathrm{Y}$ & $\mathrm{X}_{\mathbf{1}}$ & $\mathrm{X}_{\mathbf{2}}$ & $\mathrm{X}_{\mathbf{3}}$ & $\mathrm{X}_{\mathbf{4}}$ & $\mathrm{X}_{\mathbf{5}}$ \\
\hline $\mathrm{Y}$ & 1 & & & & & \\
\hline $\mathrm{X}_{\mathbf{1}}$ & 0,8589 & 1 & & & & \\
\hline $\mathrm{X}_{\mathbf{2}}$ & 0,2753 & 0,7247 & 1 & & & \\
\hline $\mathrm{X}_{\mathbf{3}}$ & 0,5685 & 0,8199 & 0,8272 & 1 & & \\
\hline $\mathrm{X}_{\mathbf{4}}$ & $-0,9914$ & $-0,7939$ & $-0,1737$ & $-0,5179$ & 1 & 1 \\
\hline $\mathrm{X}_{\mathbf{5}}$ & $-0,3977$ & $-0,7003$ & $-0,7530$ & $-0,7430$ & 0,3014 & \\
\hline
\end{tabular}

Джерело: розраховано автором

Аналіз регресії, розрахунок часткових показників і характеристик багатофакторної моделі було виконано за допомогою методу найменших квадратів та математичних функцій y середовищі MS Excel. Вагоме значення для економічного тлумачення має побудова матриці парних коефіцієнтів кореляції [9], що дає можливість визначити тісноту кореляційного зв'язку між визначеними параметрами фінансової стійкості ПрАТ «Карлсберг Україна» $з$ детермінантами моделі (табл. 6).

За даними табл. 6 видно, що між показниками існує тісний взаємозв'язок. Отримані результати свідчать, що найбільш тісний зв'язок спостерігається між результативним фактором (Y) та коефіцієнтами фінансового левериджу $\left(\mathrm{X}_{4}\right)(0,9914)$ і забезпечення оборотних активів власними оборотними коштами $\left(\mathrm{X}_{1}\right)(0,8589)$. Не менш важливими по вагомості є взаємозв'язки між коефіцієнтами маневреності власного капіталу $\left(\mathrm{X}_{2}\right)(0,8272)$ та забезпечення оборотних активів власним оборотним капіталом $\left(\mathrm{X}_{1}\right)(0,8199)$ i коефіцієнтом стійкого економічного зростання $\left(\mathrm{X}_{3}\right)$ (табл. 7).

Результати порівняння коефіцієнтів парної кореляції, розрахованих між змінними кінцевої моделі, з величиною множинного коефіцієнта кореляції $(0,9999)$ доводять, що у масиві майже не існує пар пов'язаних змінних, тобто відсутня мультиколінеарність (табл. 7). Це означає, що в масиві змінних вплив жодного фактору не розцінюється як визначальний порівняно з іншими [10]. Таким чином, можна зробити висновок, що обрані чинники можуть бути включені в одну багатофакторну модель, яка найбільш повно описує залежність між досліджуваними чинниками. 
Таблиця 7 - Тіснота та напрям зв'язку між змінними, порівняння парних коефіцієнтів кореляції з множинним коефіцієнтом кореляції

\begin{tabular}{|c|c|c|c|c|c|c|}
\hline $\begin{array}{l}\text { Коефіцієнт парної } \\
\text { кореляції }\end{array}$ & \multicolumn{3}{|c|}{$\begin{array}{c}\text { Межі модульного значення } \\
\text { коефіцієнту парної кореляції, }(<,>)\end{array}$} & $\begin{array}{l}\text { Тіснота } \\
\text { зв'язку }\end{array}$ & $\begin{array}{l}\text { Напрямок } \\
\text { зв'язку }\end{array}$ & $\begin{array}{c}\text { Характеристика } \\
\text { зв'язку }\end{array}$ \\
\hline$r\left(X_{1}, X_{2}\right)=0,7247$ & $0,7<\mid r_{1,2}$ & $<0,9,\left|r_{1,2}\right|$ & $<r_{\mathrm{\kappa p}}=0,999$ & сильний & прямий & не пов'язані \\
\hline$r\left(X_{1}, X_{3}\right)=0,8199$ & $0,7<\mid r_{1,3}$ & $<0,9,\left|r_{1,3}\right|$ & $<r_{\mathrm{\kappa p}}=0,999$ & сильний & прямий & не пов'язані \\
\hline$r\left(X_{1}, X_{4}\right)=-0,7939$ & $0,7<\mid r_{1,4}$ & $<0,9,\left|r_{1,4}\right|$ & $<r_{\mathrm{\kappa p}}=0,999$ & сильний & зворотний & не пов'язані \\
\hline$r\left(X_{1}, X_{5}\right)=-0,7003$ & $0,7<\mid r_{1,5}$ & $<0,9,\left|r_{1,5}\right|$ & $<r_{\text {кр }}=0,999$ & сильний & зворотний & не пов'язані \\
\hline$r\left(X_{1}, Y\right)=0,8589$ & $0,7<\mid r_{1, \mathrm{y}}$ & $<0,9,\left|r_{1, \mathrm{y}}\right|$ & $<r_{\text {кр }}=0,999$ & сильний & прямий & не пов'язані \\
\hline$r\left(X_{2}, X_{3}\right)=0,8272$ & $0,7<\mid r_{2,3}$ & $<0,9,\left|r_{2,3}\right|$ & $<r_{\mathrm{\kappa p}}=0,999$ & сильний & ий & оов'язані \\
\hline$r\left(X_{2}, X_{4}\right)=-0,1737$ & $0,1<\mid r_{2,4}$ & $<0,3,\left|r_{2,4}\right|$ & $<r_{\mathrm{\kappa p}}=0,999$ & слабкий & зворотний & не пов'язані \\
\hline$r\left(X_{2}, X_{5}\right)=-0,7530$ & $0,7<\mid r_{2,5}$ & $<0,9,\left|r_{2,5}\right|$ & $<r_{\mathrm{\kappa p}}=0,999$ & сильний & зворотний & не пов'язані \\
\hline$r\left(X_{2}, Y\right)=0,2753$ & $0,1<\mid r_{2, \mathrm{y}}$ & $<0,3,\left|r_{2, \mathrm{y}}\right|$ & $<r_{\text {кр }}=0,999$ & слабкий & прямий & не пов'язані \\
\hline$r\left(X_{3}, X_{4}\right)=-0,5179$ & $0,5<\mid r_{3,4}$ & $<0,7,\left|r_{3,4}\right|$ & $<r_{\text {кр }}=0,999$ & середній & зворотний & не пов'язані \\
\hline$r\left(X_{3}, X_{5}\right)=-0,7430$ & $0,7<\mid r_{3,5}$ & $<0,9,\left|r_{3,5}\right|$ & $<r_{\mathrm{\kappa p}}=0,999$ & сильний & зворотний & не пов’язані \\
\hline$r\left(X_{3}, Y\right)=0,5685$ & $0,5<\mid r_{3, \mathrm{y}}$ & $<0,7,\left|r_{3, \mathrm{y}}\right|$ & $<r_{\text {кр }}=0,999$ & середній & прямий & не пов'язані \\
\hline$r\left(X_{4}, X_{5}\right)=0,3014$ & $0,3<\mid r_{4,5}$ & $<0,5,\left|r_{4,5}\right|$ & $<r_{\mathrm{\kappa p}}=0,999$ & помірний & прямий & не пов'язані \\
\hline$r\left(X_{4}, Y\right)=-0,9914$ & $0,9<$ & $-1,0$, & $<r_{\text {кр }}=0,999$ & $\begin{array}{c}\text { дуже } \\
\text { тісний }\end{array}$ & й & ні \\
\hline$r\left(X_{5}, Y\right)=-0,3977$ & $0,3<\mid r_{5, \mathrm{y}}$ & $<0,5,\left|r_{5, \mathrm{y}}\right|$ & $<r_{\mathrm{\kappa p}}=0,999$ & помірний & зворотний & не пов'язані \\
\hline
\end{tabular}

В результаті наведених розрахунків отримано рівняння множинної регресії:

$$
y=1,981+1,077 X_{1}+0,113 X_{2}+0,716 X_{3}+0,075 X_{4}+0,683 X_{5}
$$

Таблиця 8 - Основні показники кореляційно-регресійної моделі фінансової стійкості ПрАТ «Карлсберг Україна»

\begin{tabular}{|c|c|c|c|c|}
\hline & Коефіцієнти & Стандартна помилка & t-статистика & Р-значення \\
\hline Ү-перетинання & 1,981 & 0,604 & 3,311 & 0,082 \\
\hline Змінна $\mathrm{X}_{1}$ & 1,077 & 0,040 & 27,203 & 0,023 \\
\hline Змінна $\mathrm{X}_{2}$ & 0,113 & 0,032 & $-28,682$ & 0,022 \\
\hline Змінна $\mathrm{X}_{3}$ & 0,716 & 0,026 & 27,651 & 0,023 \\
\hline Змінна $\mathrm{X}_{4}$ & 0,075 & 0,015 & 5,025 & 0,125 \\
\hline Змінна $\mathrm{X}_{5}$ & 0,683 & 0,010 & 8,235 & 0,077 \\
\hline
\end{tabular}

Джерело: розраховано автором

Коефіцієнти рівняння показують кількісний вплив кожного детермінанта на результативний показник при незмінності інших. Отже, при зростанні коефіцієнта забезпечення оборотних активів власними оборотними коштами $\left(\mathrm{X}_{1}\right)$ на 1 пункт, при незмінності інших детермінант, рівень фінансової автономії ПрАТ «Карлсберг Україна» (Y) в середньому підвищується на 1,077 пунктів. Наступним фактором збільшення коефіцієнта автономії (Y) на 0,113 пунктів, є підвищення показника маневреності власного капіталу $\left(\mathrm{X}_{2}\right)$ на 1. Збільшення коефіцієнтів стійкості економічного зростання $\left(\mathrm{X}_{3}\right)$ та фінансового левериджу $\left(\mathrm{X}_{4}\right)$ на 1 пункт в умовах незмінності інших, обумовлює підвищення показника автономії Товариства (Y) на 0,716 та 0,075 пунктів, відповідно. Тоді, за рахунок збільшення коефіцієнта рентабельності власного капіталу $\left(\mathrm{X}_{5}\right)$ фінансова стійкість $(\mathrm{Y})$ теж збільшиться у відношенні 1:0,683, при незмінності інших факторів впливу.

Наступним кроком доцільно провести оцінку достовірності отриманої моделі (табл. 9) [11]. Коефіцієнт детермінації для лінійної моделі показує, що варіація фінансової 
стійкості ПрАТ «Карлсберг Україна» на 99,9 \% визначається варіацією досліджуваних факторів.

Таблиця 9 - Оцінка достовірності економетричної моделі фінансової стійкості ПрАТ «Карлсберг Україна»

\begin{tabular}{|l|c|}
\hline \multicolumn{2}{|c|}{ Регресійна статистика } \\
\hline Коефіцієнт кореляції (множинний R) & 0,999 \\
\hline Коефіцієнт детермінації $\mathrm{R}^{2}$ & 0,999 \\
\hline Нормований $\mathrm{R}^{2}$ & 0,628 \\
\hline Стандартна помилка & 0,018 \\
\hline Спостереження & 6 \\
\hline
\end{tabular}

Джерело: розраховано автором

Результати оцінки достовірності економетричної моделі за критерієм Фішера ведено до табл. 10. Оскільки $F=159,2236$, а значущість $F=0,1482$, то модель в цілому значуща. Оскільки, Fфакm > Fтабл, то гіпотеза про значущість зв'язку приймається і модель фінансової стійкості ПрАТ «Карлсберг Україна» є статистично значуща.

Таблиця 10 - Оцінка достовірності моделі фінансової стійкості ПрАТ «Карлсберг Україна» за критерієм Фішера

\begin{tabular}{|c|c|c|c|c|c|}
\hline Дисперсійний аналіз & $\mathrm{df}$ & $\mathrm{SS}$ & $\mathrm{MS}$ & $\mathrm{F}$ & Значимість F \\
\hline Регресія & 5 & 2,6329 & 0,5266 & 159,2236 & 0,1482 \\
\hline Залишок & 1 & 0,0003 & 0,0003 & - & - \\
\hline Разом & 6 & 2,6329 & - & - & - \\
\hline
\end{tabular}

Джерело: розраховано автором

Таким чином, згідно з обчисленими характеристиками (матриця парних коефіцієнтів кореляції, коефіцієнти детермінації, кореляції, критерії Фішера), які були використані для оцінювання достовірності моделі, можна зробити висновок, що побудована нами модель відбиває тісний зв'язок між коефіцієнтами автономії, забезпечення оборотних активів власними оборотними коштами, коефіцієнтом маневреності власного капіталу, відносним показником стійкості економічного зростання Товариства та коефіцієнтом фінансового ризику. Можна стверджувати, що отримана в ході дослідження модель $\epsilon$ придатною для іiі використання з метою прогнозування фінансової стійкості ПрАТ «Карлсберг Україна» шляхом підстановки ймовірних значень фінансових показників.

Висновки. Аналіз фінансової стійкості та платоспроможності необхідний для будьякого підприємства, так як за допомогою його інструментів можна охарактеризувати фінансове становище суб'єкта господарювання. Іншими словами, це оцінка можливості своєчасності погашення своїх платіжних зобов'язань за рахунок наявних грошових ресурсів. Аналіз ліквідності балансу та платоспроможності підприємства здійснюється, грунтуючись на характеристиках ліквідності оборотних активів, і визначається проміжком часу, який необхідний для перетворення їх в грошові кошти. При цьому необхідно враховувати, що величина показника ліквідності залежить від часу на виведення даного активу, тобто чим вище ліквідність, тим менше часу необхідно для інкасації цього активу.

До локальних заходів забезпечення фінансової стійкості ПрАТ «Карлсберг Україна» можна віднести: зниження кредиторської, дебіторської заборгованості підприємства та собівартості продукції; забезпечення фінансового становища в середньостроковій перспективі, яке проявляється в стабільному надходженні виручки від реалізації, достатньому рівні ліквідності активів, підвищенні рентабельності продукції; призупинення штрафних санкцій за прострочену кредиторську заборгованість, повне забезпечення 
фінансових ресурсів для покриття поточних зобов'язань; поступове погашення старих боргів, скорочення витрат до мінімально допустимого рівня, проведення енерго- та ресурсозберігаючих заходів; створення стабільної бази для забезпечення стійкого фінансового положення Товариства в довгостроковій перспективі, створення оптимальної структури балансу та фінансової системи підприємства, раціонального розподілу фінансових результатів для уникнення наслідків несприятливого зовнішнього впливу.

Можна стверджувати, забезпечення достатнього рівня фінансової стійкості та платоспроможності як основна ціль внутрішньофірмового бюджетування, дає змогу підприємству активізувати діяльність, спрямовану на підвищення його конкурентних переваг, розвиток власного потенціалу та забезпечення економічного зростання, що позитивно вплине не лише на загальний фінансовий стан підприємства, а й на його діяльність в цілому, що можна розглядати як збалансовану в часі фінансову стійкість.

\section{СПИСОК ВИКОРИСТАНИХ ДЖЕРЕЛ}

1. Лихачева О.Н. Финансовое планирование на предприятии: Учебно-практическое пособие. М: Изд-во Проспект, 2003. 264 с.

2. Романовский М. В. Финансы, денежное обращение и кредит. М: Юрайит, 2003. 575с.

3. Бержанір I. А. Діагностика показників ліквідності підприємства. Фінансове забезпечення сталого розвитку економіки України. Умань: ФОП Жовтий О.О., 2016. $156 \mathrm{c}$.

4. Річна фінансова звітність ПрАТ «Карлсберг Україна» за 2017 рік згідно наказу Міністерства фінансів від 07.02.2013 №73 URL: https://carlsbergukraine.com/kompanya/akts-oneram/zagal-na-nformaf-ya/

5. Річна фінансова звітність ПрАТ «Карлсберг Україна» за 2018 рік URL: https://carlsbergukraine.com/kompan-ya/akts-oneram/zagal-na-nformaf-ya/

6. Річна фінансова звітність ПрАТ «Карлсберг Україна» за 2019 рік згідно наказу Міністерства фінансів від 07.02.2013 №73 URL: https://carlsbergukraine.com/kompanya/akts-oneram/zagal-na-nformaf-ya/

7. Ковалёв В. В. Финансовый анализ: методы и процедуры. М: Финансы и статистика, 2007. $560 \mathrm{c}$.

8. Христіановський В. В., Щербина В. П. Економетрика: Навчальний посібник. Вінниця: ДонНУ імені Василя Стуса, 2017. 232 с.

9. Мних С. В. Економічний аналіз: підруч. Київ: Знання, 2011. 630 с.

10. Христиановский В.В., Нескородева Т.В., Полшков Ю.Н. Экономико-математические методы и модели: практика применения в курсовых и дипломных работах: учебное пособие. Донецк: ДонНУ, 2012. 324 с.

11. Трегубов О. С., Ахновська I. О., Андронік О. Л. Економіка підприємства: навч. посіб. для студ. вищ. навч. закладів; за заг. ред. О. С. Трегубова. Вінниця: 2017. 232с.

\section{REFERENCES}

1. Lihachova O.N. (2003) Finansovoe planirovanie na predpriyatii:Uchebno-prakticheskoe posobie: M. Prospekt, $264 \mathrm{~s}$.

2. Romanovskiy M.V. (2003) Finansy, denezhnoe obrazshenie i kredit. M: Yurayin, 575 s.

3. Berzhanir I.A. (2016) Diagnostyca pokaznykiv likvidnosti pidpryyemstv. Finansove zabezpechennya stalogo rozvytku ekonomiky Ukrainy. Uman: FOP Zhovtyyi O.O., $156 \mathrm{~s}$.

4. Richna finansova zvitnist PrAT «Karlsberg Ukraina» za 2017 rik, URL: https://carlsbergukraine.com/kompan-ya/akts-oneram/zagal-na-nformaf-ya/ 
5. Richna finansova zvitnist PrAT «Karlsberg Ukraina» za 2018 rik, URL: https://carlsbergukraine.com/kompan-ya/akts-oneram/zagal-na-nformaf-ya/ 6. Richna finansova zvitnist PrAT «Karlsberg Ukraina» za 2019 rik, URL: https://carlsbergukraine.com/kompan-ya/akts-oneram/zagal-na-nformaf-ya/

7. Kovalyov V.V. (2007) Finansovysy analiz: metody i procedury. M: Finansy i statistika, $560 \mathrm{~s}$.

8. Hrystianovskiyi V.V., Zsherbyna V.N. (2017) Ekonometrika: Navchalnyyi posabnyk. Vinnitsa: DonNU imeni Vasylya Stusa, 232 s.

9. Mnyh Ye.V. (2011) Ekonomichnyyi analiz: pidruchnyk. Kyyiv: Znannya, $630 \mathrm{~s}$.

10. Hrystianovskiyi V.V., Nyeskorodyeva N.V., Polshkov Yu.N. (2012) Ekonomikomatematicheskie metodyi modeli: uchebnoe posobie. Doneck: DonNU, 324 s.

11. Tregubov O.S., Ahnovska I.O., Andronik O.L. (2017) Ekonomika pidpryyemstva: navch. posibn. dlya stud. Vyzsh. Navch. zakladiv, Vinnitsa: DonNU imeni Vasylya Stusa, 232 s.

Болгов В.Е., к.е.н., доцент кафедры предпринимательства, корпоративной и пространственной экономики, Донецкий национальный университет имени Васыля Стуса, г. Винница

Вытяганец И.Н., Донецкий национальный университет имени Васыля Стуса, г. Винница

\section{ОБЕСПЕЧЕНИЕ ФИНАНСОВОЙ УСТОЙЧИВОСТИ И ПЛАТЕЖЕСПОСОБНОСТИ} КАК ВАЖНАЯ ЦЕЛЬ ВНУТРИФИРМЕННОГО БЮДЖЕТИРОВАНИЯ

В статье обоснованы теоретические положения и практические рекомендации по оценке платежеспособности и финансовой устойчивости предприятия, определены приоритеты и разработаны системы средств повышения финансовой независимости ЧАО «Карлсберг Украина». Рассмотрены сущностные характеристики бюджетирования как инструмента внутрифирменного финансового планирования. Исследован механизм обеспечения таких понятий как финансовая устойчивость, ликвидность, платежеспособности предприятия, проанализировать факторы, оказывают существенное влияние на их формирование и поддержку. Обоснован методический подход оценки финансовой устойчивости ЧАО «Карлсберг Украина». Проведен анализ ликвидности и платежеспособности предприятия. Осуществлено моделирование финансовой устойчивости ЧАО «Карлсберг Украина» с перспективой повышения эффективности его хозяйственной деятельности. Выявлены и предложены пути повышения эффективности использования финансовых ресурсов с помощью факторного анализа рентабельности собственного капитала ЧАО «Карлсберг Украина».

Ключевье слова: бюджетирование, мотивация, механизм, финансовая устойчивость, платежеспособность, анализ.

V. Bolhov, Ph.D., Associate Professor Department of Entrepreneurship, Corporate and Spatial Economics, Vasyl Stus Donetsk National University

I. Vytiahanets, Vasyl` Stus Donetsk National University

\section{ENSURING FINANCIAL SUSTAINABILITY AND PAYMENT CAPACITY AS AN IMPORTANT OBJECTIVE OF INTERNAL BUDGETING}

The statistic has established theoretical ambushes and practical recommendations for assessing the feasibility and financial strength of an enterprise, priorities are assigned and the system has been broken up to create the financial independence of Ukraine. The day-to-day characteristics of the budget are seen as to the tool of the internal financial plan. The mechanism of securing such a thing has been understood as the financial efficiency, liquidity, platform-ability of the enterprise, to analyze the factor, so that it's possible to get the message flowing into the 
form and the picture. A methodical approach to the assessment of the financial performance of the Carlsberg Ukraine PrAT has been established. An analysis of the liquidity and plateau-ability of the enterprise was carried out. The model of the financial stability of the PRAT "Carlsberg Ukraine" has been developed with the prospect of improving the efficiency of the government's activity. It was revealed that the promises were made to advance the efficiency of financial resources for an additional factor analysis of the profitability of the capital of the PRAT "Carlsberg Ukraine".

Key words: budgeting, motivation, mechanism, financial stability, solvency, analysis 